\title{
Unique prostate cancer-toxic polyketides from marine sediment-derived fungus Isaria felina
}

\author{
Olga F Smetanina ${ }^{1,4}$, Anton N Yurchenko ${ }^{1,2,4}$, Elena V Ivanets ${ }^{2}$, Anatoly I Kalinovsky ${ }^{1}$, Yuliya V Khudyakova ${ }^{1}$, \\ Sergey A Dyshlovoy ${ }^{1,2,3}$, Gunhild von Amsberg ${ }^{3}$, Ekaterina A Yurchenko ${ }^{1}$ and Shamil Sh Afiyatullov ${ }^{1}$
}

The Journal of Antibiotics (2017) 70, 856-858; doi:10.1038/ja.2017.53; published online 26 April 2017

Marine-derived fungi are very promising source of structurally unique and biologically active secondary metabolites. From the beginning of the twenty-first century, the discovery of new natural compounds from marine fungi has been extensively increased annually. ${ }^{1,2}$

The usual approaches to change metabolite producing and to obtain new compound from fungi are cultivation with addition halogen salts and mixed cultivation with other microorganisms. Cultivation using media with high concentration of bromide or iodide ions often allows to obtain metabolites with bromine and iodine atoms, respectively. ${ }^{3,4}$

As shown in recent studies co-cultivation of fungi with other fungal and bacterial strains stimulated the organisms to produce new compounds via induction of silent fungal biosynthetic gene clusters. Thus, mixed culture produce metabolites not typical for single cultures. $^{5-7}$

The fungus Isaria felina (=Beauveria felina) KMM 4639 has been reported to be a producer of high oxygenated chromene derivatives and some other compounds more than once as a result of cultivation under different conditions. ${ }^{8-10}$ To continue these studies, we changed cultivation condition and added potassium bromide. In addition, we co-cultured this strain with another fungus Aspergillus sulphureus KMM 4640 previously synthesized polyketide decalines together with alkaloid brevianamide F. ${ }^{11}$ Recently one new aromatic compound was obtained from mixed culture of these fungal strains under other conditions. ${ }^{12}$

The fungal strain Isaria felina KMM 4639 was isolated and identified as described in previous publications. ${ }^{10}$ For this study, the fungus was cultivated for 3 weeks in $20 \times 0.51$ Erlenmeyer flasks with rice medium $\left(20 \mathrm{~g}\right.$ rice, $20 \mathrm{mg}$ yeast extract, $10 \mathrm{mg} \mathrm{KH}_{2} \mathrm{PO}_{4}, 1.8 \mathrm{~g} \mathrm{KBr}, 40 \mathrm{ml}$ natural sea water per flask). The fungal mycelia with the medium were extracted twice for $24 \mathrm{~h}$ with 61 of EtOAc. Evaporation of the solvent under reduced pressure gave a brown oil $(1.2 \mathrm{~g})$, to which $250 \mathrm{ml}$ $\mathrm{H}_{2} \mathrm{O}$-EtOH (4:1) was added, and the combination was thoroughly mixed to yield a suspension. It was extracted successively with hexane $(150 \mathrm{ml} \times 2)$, EtOAc $(150 \mathrm{ml} \times 2)$ and $n$-BuOH $(150 \mathrm{ml} \times 2)$. The EtOAc fraction was concentrated in vacuo to give a residue $(0.4 \mathrm{~g})$, which was separated on a silica gel column $(30 \times 2 \mathrm{~cm})$ eluted with a hexane-EtOAc gradient $(1: 0-0: 1)$. The hexane-EtOAc fraction IFBr-1-36 (87.5:12.5, $58 \mathrm{mg}$ ) was purified by Sephadex LH-20 column chromatography eluting with $\mathrm{CHCl}_{3}$ to yield $1(5.2 \mathrm{mg})$. The hexaneEtOAc fraction IFBr-1-69 (80:20, $11 \mathrm{mg})$ was separated by Sephadex LH-20 column chromatography eluting with $\mathrm{CHCl}_{3}$ to yield the 2 $(2.2 \mathrm{mg})$. In addition, known oxirapentyns $\mathrm{B}^{8}, \mathrm{E}^{9}$ and $\mathrm{F}^{10}$ were also isolated from these fractions.

Isariketide B (2) (Figure 1) was obtained as colorless oil. The UV (EtOH) of 2 was $\lambda_{\max }(\log \varepsilon) 235$ (4.03), 336 (3.60) nm.

The molecular formula of 2 was determined as $\mathrm{C}_{12} \mathrm{H}_{14} \mathrm{O}_{7}$ based on the analysis of HRESIMS $\left(\mathrm{m} / z \quad 293.0640 \quad[\mathrm{M}+\mathrm{Na}]^{+}\right.$, calcd for $\left.\mathrm{C}_{12} \mathrm{H}_{14} \mathrm{O}_{7} \mathrm{Na}, 293.0637\right)$ and NMR data. An analysis of ${ }^{1} \mathrm{H}$ and ${ }^{13} \mathrm{C}$ NMR data (Table 1 and Supplementary Data S2-S3) together with DEPT and HSQC data revealed the presence of two methoxyls $\left(\delta_{\mathrm{C}} 63.4,52.2, \delta_{\mathrm{H}} 4.17,3.82\right)$, two oxygenated methylenes $\left(\delta_{\mathrm{C}} 55.9\right.$, $\left.54.9, \delta_{\mathrm{H}} 4.63,4.60\right)$ and two $s p^{2}$ methines $\left(\delta_{\mathrm{C}} 130.3,125.5, \delta_{\mathrm{H}} 7.58\right.$, $6.80)$. The remaining six carbon signals were assigned to two carboxyls $\left(\delta_{\mathrm{C}} 167.5,166.2\right)$, two oxygen-bearing quaternary $s p^{2}$ carbons $\left(\delta_{\mathrm{C}} 163.7,153.3\right)$ and two quaternary $s p^{2}$ carbons $\left(\delta_{\mathrm{C}} 118.4,114.6\right)$.

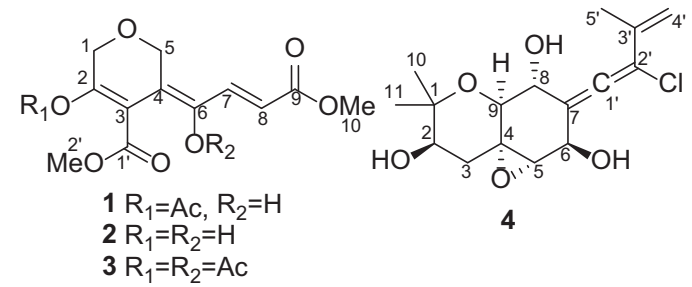

Figure 1 Structures of compounds $1-4$.

${ }^{1}$ GB Elyakov Pacific Institute of Bioorganic Chemistry Far Eastern Branch of Russian Academy of Science, Vladivostok, Russia; ${ }^{2}$ Far Eastern Federal University, Vladivostok, Russia and ${ }^{3}$ Department of Oncology, Hematology and Bone Marrow Transplantation with Section Pneumology, Hubertus Wald-Tumorzentrum, University Medical Center HamburgEppendorf, Hamburg, Germany

${ }^{4}$ These authors contributed equally to this work.

Correspondence: Dr AN Yurchenko, GB Elyakov Pacific Institute of Bioorganic Chemistry Far Eastern Branch of Russian Academy of Science, Prospect 100-Letiya Vladivostoka, 159, Vladivostok 690022, Russia.

E-mail: yurchant@ya.ru

Received 17 January 2017; revised 23 March 2017; accepted 24 March 2017; published online 26 April 2017 
A similarity of NMR data of compound 2 (Supplementary Data S4) with those of known isariketide A $(\mathbf{1})^{10}$ and the molecular mass difference (42 mass units) between these compounds suggested the presence of a hydroxyl group in $\mathbf{2}$ instead of the acetyl group in $\mathbf{1}$. To the best of our knowledge, isariketides A and B are the only examples of unique $\alpha$-unsubstituted pyrane polyketide.

For study of the effect of acetyl group introduction on bioactivity compound $\mathbf{1}(1.4 \mathrm{mg})$ was acetylated by acetic anhydride to yield compound 3 (1.4 mg) (Figure 1).

In next step the fungus Isaria felina KMM 4639 was co-cultivated with another fungus Aspergillus sulphureus KMM 4640. Fungus A. sulphureus was isolated from marine sediments and identified as described earlier. ${ }^{11}$ Fungi I. felina and A. sulphureus were cultivated separately on rice medium ${ }^{9}$ for 1 week. Then A. sulphureus mycelium was inoculated into $3 \times 0.51$ Erlenmeyer flasks with $I$. felina culture. After that fungal cultures were cultivated together for 2 weeks and then were extracted twice for $24 \mathrm{~h}$ with 1.21 of EtOAc. Evaporation of the solvent under reduced pressure gave a brown oil ( $1.65 \mathrm{~g})$, to which $250 \mathrm{ml} \mathrm{H}_{2} \mathrm{O}$-EtOH (4:1) was added and the combination was thoroughly mixed to yield a suspension. It was extracted successively with hexane $(150 \mathrm{ml} \times 2)$, EtOAc $(150 \mathrm{ml} \times 2)$ and $n-\mathrm{BuOH}$

Table 1 NMR spectroscopic data $\left(700 \mathrm{MHz}, \mathrm{CDCl}_{3}\right)$ for isariketide B (2) and oxirapentyn L (4)

\begin{tabular}{|c|c|c|c|c|}
\hline \multirow[b]{2}{*}{ Atom } & \multicolumn{2}{|c|}{ Isariketide $B(2)$} & \multicolumn{2}{|c|}{ Oxirapentyn $L$ (4) } \\
\hline & $\delta_{C}$, mult & $\delta_{H}, m(J$ in $H z)$ & $\delta_{C}$, mult & $\delta_{H}, m(J$ in $H z)$ \\
\hline 1 & $55.9, \mathrm{CH}_{2}$ & $4.63, \mathrm{~d}(5.0)$ & $76.1, \mathrm{C}$ & \\
\hline 2 & 163.7, C & & $72.6, \mathrm{CH}$ & $3.72, \mathrm{t}(3.3)$ \\
\hline 3 & $114.6, \mathrm{C}$ & & $34.9, \mathrm{CH}_{2}$ & $\begin{array}{l}2.52, \text { dd }(13.7,3.0) \\
1.68, \text { dd }(13.7,3.7)\end{array}$ \\
\hline 4 & $118.4, \mathrm{C}$ & & $57.8, \mathrm{C}$ & \\
\hline 5 & $54.9, \mathrm{CH}_{2}$ & $4.60, \mathrm{~d}(3.0)$ & $63.7, \mathrm{CH}$ & $3.35, \mathrm{~s}$ \\
\hline 6 & 153.3, C & & $64.9, \mathrm{CH}$ & $4.90, \mathrm{~s}$ \\
\hline 7 & $130.3, \mathrm{CH}$ & $7.58, \mathrm{~d}(15.5)$ & $111.4, \mathrm{C}$ & \\
\hline 8 & $125.5, \mathrm{CH}$ & $6.80, d(15.5)$ & $71.0, \mathrm{CH}$ & $4.30, \mathrm{~m}$ \\
\hline 9 & $166.2, \mathrm{C}$ & & $70.7, \mathrm{CH}$ & 4.13, brd (3.5) \\
\hline 10 & $52.2, \mathrm{CH}_{3}$ & $3.82, \mathrm{~s}$ & $25.1, \mathrm{CH}_{3}$ & $1.25, \mathrm{~s}$ \\
\hline 11 & & & $22.1, \mathrm{CH}_{3}$ & $1.40, \mathrm{~s}$ \\
\hline $1^{\prime}$ & $167.5, \mathrm{C}$ & & $198.2, \mathrm{C}$ & \\
\hline $2^{\prime}$ & $63.4, \mathrm{CH}_{3}$ & $4.17, \mathrm{~s}$ & $111.8, \mathrm{C}$ & \\
\hline $3^{\prime}$ & & & $136.2, \mathrm{C}$ & \\
\hline $4^{\prime}$ & & & $116.4, \mathrm{CH}_{2}$ & $\begin{array}{l}5.52, \mathrm{~s} \\
5.15, \mathrm{~s}\end{array}$ \\
\hline $5^{\prime}$ & & & 20.9, $\mathrm{CH}_{3}$ & $1.90, \mathrm{~s}$ \\
\hline
\end{tabular}

$(150 \mathrm{ml} \times 2)$. The EtOAc fraction was concentrated in vacuo to give a residue $(0.8 \mathrm{~g})$, which was separated on a silica gel column $(30 \times 2 \mathrm{~cm})$ eluted with a hexane-EtOAc gradient $(1: 0-0: 1)$. The hexane-EtOAc fraction IFAS-1-22 (70:30, $79 \mathrm{mg})$ was purified by reverse phase HPLC on Supelco Discovery $\mathrm{C}_{18}$ column eluting with $\mathrm{MeOH}-\mathrm{H}_{2} \mathrm{O}$ (55:45) to yield 4 (1.5 mg). Besides 4, known oxirapentyns $\mathrm{A}, \mathrm{B}, \mathrm{D}-\mathrm{I}^{8-10}$ were isolated from this extract.

Oxirapentyn L (4) (Figure 1) was obtained as white amorphous powder. The optical rotation value was $\alpha_{\mathrm{D}}^{20}-23^{\circ}(\mathrm{c} 0.12, \mathrm{MeOH})$.

An HRESIMS spectrum of compound 4 contained $[\mathrm{M}+\mathrm{Na}]^{+}$peak at $\mathrm{m} / \mathrm{z} 351.0969$, showing the characteristic isotope pattern for one chlorine atom (Supplementary Data S10). These data indicated a molecular formula of $\mathrm{C}_{16} \mathrm{H}_{21} \mathrm{ClO}_{5}$ (calcd for $\mathrm{C}_{16} \mathrm{H}_{21} \mathrm{ClNaO}_{5}$, 351.0970), which corresponded to six double-bond equivalents.

A direct comparison of ${ }^{1} \mathrm{H}$ and ${ }^{13} \mathrm{C}$ NMR spectra of 4 (Table 1 and Supplementary Data S5-S7) with those for known oxirapentyn $\mathrm{E}^{9}$ revealed a number of similarities. These data included signals for two methyls $\left(\delta_{\mathrm{C}} 25.1,22.1, \delta_{\mathrm{H}} 1.40,1.25\right)$, one methylene $\left(\delta_{\mathrm{C}} 34.9\right.$, $\left.\delta_{\mathrm{H}} 2.52,1.68\right)$, one oxygenated methine $\left(\delta_{\mathrm{C}} 72.6, \delta_{\mathrm{H}} 3.72\right)$ and one oxygen-bearing $s p^{3}$-quaternary carbon $\left(\delta_{\mathrm{C}} 76.1\right)$. HMBC correlations (Figure 2 and Supplementary Data S8) from $\mathrm{H}-2\left(\delta_{\mathrm{H}} 3.72\right)$ to $\mathrm{C}-3$ $\left(\delta_{\mathrm{C}} 34.9\right)$ and $\mathrm{C}-4\left(\delta_{\mathrm{C}} 57.8\right)$, from $\mathrm{H}_{2}-3\left(\delta_{\mathrm{H}} 2.52,1.68\right)$ to $\mathrm{C}-1$ $\left(\delta_{\mathrm{C}} 76.1\right), \mathrm{C}-2\left(\delta_{\mathrm{C}} 72.6\right), \mathrm{C}-4$ and C-9 $\left(\delta_{\mathrm{C}} 70.7\right)$ together with HMBC cross peaks from both of $\mathrm{H}_{3}-10\left(\delta_{\mathrm{H}} 1.25\right)$ and $\mathrm{H}_{3}-11\left(\delta_{\mathrm{H}} 1.40\right)$ to $\mathrm{C}-1$ and $\mathrm{C}-2$ confirmed that pyrane ring in 4 is identical with that in oxirapentyns $\mathrm{E}$ and $\mathrm{G}^{10}$. Second ring was established by $\mathrm{HMBC}$ correlations from $\mathrm{H}-5\left(\delta_{\mathrm{H}} 3.35\right)$ to $\mathrm{C}-4, \mathrm{C}-6\left(\delta_{\mathrm{C}} 64.9\right)$ and $\mathrm{C}-7$ $\left(\delta_{\mathrm{C}} 111.4\right)$, from H-6 $\left(\delta_{\mathrm{H}} 4.90\right)$ to $\mathrm{C}-4, \mathrm{C}-5\left(\delta_{\mathrm{C}} 63.7\right), \mathrm{C}-7$ and C-8 $\left(\delta_{\mathrm{C}} 71.0\right)$, and from $\mathrm{H}-9\left(\delta_{\mathrm{H}} 4.13\right)$ to $\mathrm{C}-4, \mathrm{C}-5, \mathrm{C}-7$ and $\mathrm{C}-8$. The structure and location of the side chain was determined by HMBCs from $\mathrm{H}-4^{\prime}$ to $\mathrm{C}-7, \mathrm{C}-2^{\prime}\left(\delta_{\mathrm{C}} 111.8\right), \mathrm{C}-3^{\prime}\left(\delta_{\mathrm{C}} 136.2\right)$ and $\mathrm{C}-5^{\prime}\left(\delta_{\mathrm{C}} 20.9\right)$, from $\mathrm{H}_{3}-5^{\prime}\left(\delta_{\mathrm{H}} 1.90\right)$ to $\mathrm{C}-2^{\prime}, \mathrm{C}-3^{\prime}$ and $\mathrm{C}-4^{\prime}\left(\delta_{\mathrm{C}} 116.4\right)$ as well as from H-6 to C-1' $\left(\delta_{\mathrm{C}}\right.$ 198.2). These data showed that compound 4 was derivative of oxirapentyn $G$ with methylbutadienylidene side chain
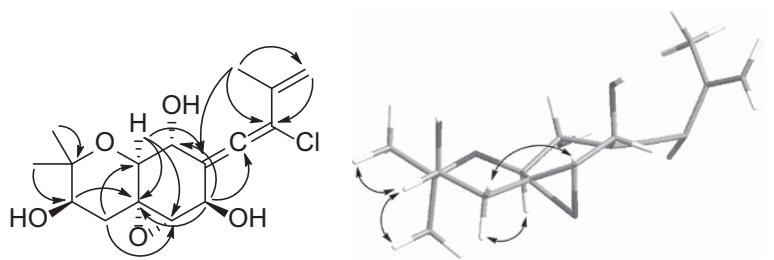

Figure 2 Key HMBC $(\rightarrow)$ and ROESY $(\leftrightarrow)$ correlations in oxirapentyn $L(4)$. Energy-minimized 3D model was obtained using Chem3D software. A full colour version of this figure is available at the Journal of Antibiotics journal online.

Table 2 Cytotoxic activity of compounds $1-4$

\begin{tabular}{|c|c|c|c|c|c|}
\hline \multirow[b]{2}{*}{ Compound } & \multicolumn{5}{|c|}{$I_{50, \mu M}$} \\
\hline & $22 R v 1$ & $P C-3$ & LNCaP & Murine splenocytes & Murine erythrocytes \\
\hline Isariketide A (1) & 3.2 & 4.9 & 14.3 & $>100$ & $>100$ \\
\hline Isariketide B (2) & $>100$ & $>100$ & $>100$ & $>100$ & $>100$ \\
\hline Isariketide A acetate (3) & 1.17 & 3.25 & 6.31 & 69.7 & 38.7 \\
\hline Oxirapentyn L (4) & $>100$ & $>100$ & $>100$ & $\mathrm{n} / \mathrm{t}^{\mathrm{b}}$ & $\mathrm{n} / \mathrm{t}^{\mathrm{b}}$ \\
\hline Docetaxel $^{\mathrm{a}}$ & 0.013 & 0.015 & 0.004 & $n / t^{b}$ & $n / t^{b}$ \\
\hline
\end{tabular}

aDocetaxel was used as a reference compound.

'The compound was not tested. 
instead of methylbutenynyl side chain. The location of chlorine atom at C-2' was suggested by downfield chemical shift of C-2' in 4 compared with similar known truncateol A. ${ }^{13}$

ROESY correlations (Supplementary Data S9) $\mathrm{H}-2 / \mathrm{H}_{3}-10$ and $\mathrm{H}_{3}-11, \mathrm{H}-3 \beta / \mathrm{H}-5$, and $\mathrm{H}-3 \alpha / \mathrm{H}-9$ together with undoubted biogenetic relationship with known oxirapentyns $\mathrm{G}$ and $\mathrm{F}^{10}$ suggested the absolute configurations of all chiral centers in $\mathbf{4}$ as depicted (Figure 2). It should be noted that several oxirapentyn-related compounds with allenic side chain were reported recently. ${ }^{13}$ Nevertheless, oxirapentyn $\mathrm{L}$ is the first and the only example of natural compound with chloroallenic moiety.

We have investigated the effect of the compounds $1-4$ on viability and apoptosis induction of human prostate cancer cells ${ }^{14-16}$ and murine non-malignant splenocytes and erythrocytes. MTT assay revealed 1 and 3 to be highly cytotoxic in 22Rv1, PC-3 and LNCaP cells (Table 2). Furthermore, isariketide A (1) did not show cytotoxicity to murine splenocytes and erythrocytes up to $100 \mu \mathrm{M}$, and isariketide A acetate (3) showed cytotoxicity to these cells only in high doses (Table 2). Thus, degree of acetylation increases cytotoxicity of isariketides. Additionally, we were able to demonstrate that $\mathbf{1}$ and $\mathbf{3}$ induce apoptosis of human cancer 22Rv1 cells $(17.3 \pm 0.1 \%$ and $60.9 \pm 12.2 \%$ apoptosis after treatment with $5 \mu \mathrm{M}$ for $48 \mathrm{~h}$, respectively). Other compounds did not exhibit cytotoxic activity against human prostate cancer cells at concentrations of up to $100 \mu \mathrm{M}$. No significant effect on cell cycle progression was observed for any compound at concentrations of up to $100 \mu \mathrm{M}$. 22Rv1 and PC-3 cells are known to be resistant to the hormone therapy due to the presence of androgen receptor (AR) splice variant AR-V7 (22Rv1 cells) or absence of AR ( $\mathrm{PC}-3$ cells), while LNCaP cells bearing w/t AR are sensitive to the hormone deprivation. ${ }^{17}$ Remarkably, $\mathbf{1}$ and 3 were even more active in drug-resistant 22Rv1 and PC-3 cells when compared with drug-sensitive LNCaP cells. Therefore, these two compounds may be promising candidates for the therapy of human drug-resistant prostate cancer.

\section{CONFLICT OF INTEREST}

The authors declare no conflict of interest.

\section{ACKNOWLEDGEMENTS}

The study was supported by Russian Foundation of Basic Research (Grant No. 15-29-02572) in the field of microbiological studies.

1 Blunt, J. W., Copp, B. R., Keyzers, R. A., Munro, M. H. \& Prinsep, M. R. Marine natural products. Nat. Prod. Rep. 33, 382-431 (2016).

2 Ebada, S. \& Proksch, P. in Springer Handbook of Marine Biotechnology (ed. Kim, S.-K.) 759-788 (Springer, Berlin Heidelberg, Berlin, 2015).

3 Yamazaki, $\mathrm{H}$, Rotinsulu, $\mathrm{H}$, Narita, $\mathrm{R}$, Takahashi, $\mathrm{R}$ \& Namikoshi, M. Induced production of halogenated epidithiodiketopiperazines by a marine-derived Trichoderma cf. brevicompactum with sodium halides. J. Nat. Prod. 78, 2319-2321 (2015).

4 Huang, $\mathrm{H}$. et al. Halogenated anthraquinones from the marine-derived fungus Aspergillus sp. SCSIO F063. J. Nat. Prod. 75, 1346-1352 (2012).

5 Pettit, R. K. Mixed fermentation for natural product drug discovery. Appl. Microbiol. Biotechnol. 83, 19-25 (2009).

6 Marmann, A., Aly, A. H., Lin, W., Wang, B. \& Proksch, P. Co-cultivation - a powerful emerging tool for enhancing the chemical diversity of microorganisms. Mar. Drugs. 12, 1043-1065 (2014).

7 Netzker, T. et al. Microbial communication leading to the activation of silent fungal secondary metabolite gene clusters. Front. Microbiol. 6, 299 (2015).

8 Smetanina, O. F. et al. Oxirapentyns B-D produced by a marine sediment-derived fungus Isaria felina (DC.) Fr. Phytochem. Lett. 5, 165-169 (2012).

9 Yurchenko, A. N. et al. New oxirapentyn E from marine isolate of the fungus Isaria felina. Chem. Nat. Compd. 49, 857-860 (2013).

10 Yurchenko, A. N. et al. Oxirapentyns F-K from the marine-sediment-derived fungus Isaria felina KMM 4639. J. Nat. Prod. 77, 1321-1328 (2014).

11 Zhuravleva, O. I. et al. A new cytotoxic decaline derivative from the marine fungus Aspergillus sulphureus KMM 4640. Arch. Pharm. Res. 35, 1757-1762 (2012).

12 Zhuravleva, O. I. et al. New diorcinol j produced by co-cultivation of marine fungi Aspergillus sulphureus and Isaria felina. Chem. Nat. Compd. 52, 227-230 (2016).

13 Zhao, Y. et al. New isoprenylated cyclohexanols from the sponge-associated fungus Truncatella angustata with anti-H1N1 virus activities. Tetrahedron 71, 2708-2718 (2015).

14 Dyshlovoy, S. A. et al. The marine triterpene glycoside frondoside A exhibits activity in vitro and in vivo in prostate cancer. Int. J. Cancer 138, 2450-2465 (2016)

15 Dyshlovoy, S. A. et al. Marine alkaloid monanchocidin a overcomes drug resistance by induction of autophagy and lysosomal membrane permeabilization. Oncotarget 6, 17328-17341 (2015).

16 Dyshlovoy, S. A. et al. Activity of aaptamine and two derivatives, demethyloxyaaptamine and isoaaptamine, in cisplatin-resistant germ cell cancer. J. Proteomics 96, 223-239 (2014).

17 Liu, C. et al. Niclosamide inhibits androgen receptor variants expression and overcomes enzalutamide resistance in castration-resistant prostate cancer. Clin. Cancer Res. 20, 3198-3210 (2014).

Supplementary Information accompanies the paper on The Journal of Antibiotics website (http://www.nature.com/ja) 